ISSN 0258-7122

Bangladesh J. Agril. Res. 40(2): 305-323, June 2015

\title{
GENETIC VARIABILITY, CHARACTER ASSOCIATION AND PATH ANALYSIS IN BRASSICA rapa L. GENOTYPES
}

\author{
S. NAZNIN ${ }^{1}$, M. A. KAWOCHAR ${ }^{2}$, S. SULTANA ${ }^{3}$ AND M. S. R. BHUIYAN ${ }^{4}$
}

\begin{abstract}
Thirty three genotypes of Brassica rapa L. were evaluated in order to find out their inter-genotypic variability; character association and path coefficient of seed yield/plant and its component characters. BARI sarisha-6 x TORI-7 S-45 showed best result in terms of early maturity (75 days) and higher seed yield/plant $(5.28 \mathrm{~g})$ than check varieties. The character, plant height, was highly influenced by the environment whereas, all other characters influenced the least. Number of secondary branches/plant showed the highest phenotypic and genotypic coefficient of variation. Moreover, number of siliquae/plant, number of secondary branches/plant and number of primary branches/plant showed high heritability $(93.16 \%, 75.69 \%$ and $68.03 \%$, respectively) couple with high genetic advance in percent of mean $(37.74 \%, 73.55 \%$ and $26.82 \%$, successively). The seed yield/plant showed significant positive correlation with number of siliquae/plant $\left(r_{\mathrm{g}}=0.7011^{* *}, r_{\mathrm{p}}=0.5684^{* *}\right)$, number of primary branches/plant $\left(r_{g}=0.5611^{* *}, r_{p}=0.4016^{*}\right)$ and number of secondary branches/plant $\left(r_{g}=0.5160^{* *}, r_{p}=0.4098^{*}\right)$ revealing that selection based on these traits would be judicious. Path analysis showed that the number of siliquae/plant (0.4679), number of primary branches/plant (0.2823) and number of secondary branches/plant (0.0092) were the most important contributors to seed yield/plant. The results indicated that number of siliquae/plant, number of primary branches/plant and number of secondary branches/plant can be used as selection criteria to increase seed yield/plant in rapeseed.
\end{abstract}

Keywords: Genetic variability, heritability, character association, path analysis, Brassica rapa $\mathrm{L}$.

\section{Introduction}

The seeds of Brassica rapa L. contain $42 \%$ oil and $25 \%$ protein (Khaleque, 1985). It also serves as important source of raw material for industrial use such as in making soaps, paints, hair oils, lubricants, textile auxiliaries, pharmaceuticals and so on. On the other hand, oil cakes and meals are used as animal feeds and manures. Brassica rapa L. occupies the first position in respect of area and production among the oil crops grown in Bangladesh (Anonymous, 2011). In this country, 0.252 million hectare of land was under rapeseed and mustard cultivation where produced about 0.271 million tons of seed with national

${ }^{1,2 \& 3}$ Scientific Officer (Plant Breeding), Tuber Crops Research Centre, Bangladesh Agricultural Research Institute (BARI), Gazipur-1701, ${ }^{4}$ Professor, Department of Genetics and Plant Breeding, Sher-e-Bangla Agricultural University, Dhaka-1207, Bangladesh. 
average yield of 1.075 ton/ha during 2010-2011. Total annual edible oil production was about 0.833 million tons which is very low against the requirement of Bangladesh. Bangladesh imported 89.97 thousand tons of edible oil of rapeseed to meet up the annul requirement in the year of 2010-2011, which costs Tk.3718.457 million (Anonymous, 2011). The main reasons behind these are the use of low yielding local indigenous cultivars and low management practices (Hasanuzzaman and Karim, 2007). Although number of high yielding varieties have been released but short duration high yielding varieties are not enough. Thus, farmers still use low yielding indigenous varieties. Therefore, high yielding and short duration Brassica rapa $\mathrm{L}$. varieties need to be developed to fit into the existing cropping pattern (Rice-Mustard-Rice).

Analysis of variability among the traits and the association of a particular character in relation to other traits contributing to yield of a crop would be of great importance in planning a successful breeding program (Mary and Gopalan 2006). Development of high-yielding cultivars is required a thorough knowledge of the existing genetic variation for yield and its components. The observed variability is a combined estimate of genetic and environmental causes, of which only the former one is heritable. However, estimates of heritability alone do not provide an idea about the expected gain in the next generation, but have to be considered in conjunction with estimates of genetic advance, the change in mean value among successive generations (Shukla et al., 2006). Seed yield is a complex character that can be determined by several components reflecting positive or negative effect upon this trait, whereas it is important to examine the contribution of each of the various components in order to give more attention to those having the greatest influence on seed yield (Marjanovic-Jeromela et al., 2007). Determination of correlation coefficients is an important statistical procedure to evaluate breeding programs for high yield, as well as to examine direct and indirect contributions to yield variables (Ali et al., 2003). Pathcoefficient technique splits the correlation coefficients into direct and indirect effect via alternative characters or pathways and thus permits a critical examination of components that influence a given correlation and can be helpful in formulating an efficient selection strategy (Sabaghnia et al., 2010). Therefore, correlation in combination with the path coefficient analysis quantifies the direct and indirect contribution of one character upon another (Dewey and Lu, 1959). Hence the present study was conducted to find out the variability, character association and the direct and indirect effect of different characters on yield which are very important for launching an effective breeding program to select the desired plant types to meet the existing demand.

\section{Materials and Method}

Thirty-three Brassica rapa L. genotypes were used in this experiment where three of them were used as check. Among the genotypes, thirty were selected from $\mathrm{F}_{9}$ 
segregating generation on the basis of their variation in different traits. The experiment was laid out in Randomized Complete Block Design with three replications at the field of Sher-e-Bangla Agricultural University farm, Dhaka, during rabi, 2011-2012. Each plot was $3 \mathrm{~m}$ long with two rows. Distance between row- row $30 \mathrm{~cm}$ and plant-plant $10 \mathrm{~cm}$ and block-block $1 \mathrm{~m}$ were maintained. Recommended doses of fertilizers and standard cultural practices were applied for raising healthy crops. Data were recorded on days to maturity, plant height $(\mathrm{cm})$, number of primary branches/plant, number of secondary branches/plant, number of siliquae/plant, siliqua length $(\mathrm{cm})$, number of seeds/siliqua, 1000 seed weight $(\mathrm{g})$ and seed yield/plant (g). All the collected data of the study were used to statistical analysis. Analysis of variance (ANOVA), mean, range were calculated by using MSTATC software program and then phenotypic and genotypic variance was estimated by the formula used by Johnson et al. (1955). Genotypic and phenotypic co-efficient of variation were calculated by the formula of Burton (1952) and values were categorized as low (0-10\%), moderate (10-20\%) and high (20\% and above) as suggested by Shivasubramanian and Menon (1973). Heritability was measured using the formula given by Singh and Chaudhary (1985) and the heritability percentage was categorized as low $(0-30 \%)$, moderate $(30-60 \%)$ and high (60\% and above) as given by Robinson et al. (1949). Genetic advance for different characters under selection was suggested by Allard (1960). Genetic advance in percentage of mean was calculated and values were categorized as low (0-10\%), moderate (10-20\%) and high (20\% and above) as per Johnson et al. (1955). Genotypic and phenotypic correlation coefficient was obtained using the formula suggested by Miller et al. (1958); and path co-efficient analysis was done following the method outlined by Dewey and Lu (1959).

\section{Results and Discussion}

\section{Variability, heritability and genetic advance}

Highly significant variation was observed among the genotypes for all the characters under study which revealed the presence of considerable variability among the studied genotypes. The number of siliquae/plant showed the highest range of variation (78.00 -180.33) which means the presence wide range of variation for this character. This character also showed the highest mean value (130.79). [Table 1]

BARI sarisha-6 $x$ TORI-7 S-45 showed the earliest maturity (75 days) with higher yield/plant (5.28g) than check varieties. BARI sarisha-6 x TORI-7 S-62, BARI sarisha-6 x TORI-7 S-37, BARI sarisha-9 x BARI sarisha-6 S-62, BARI sarisha-6 x TORI-7 S-11 and BARI sarisha-6 x TORI-7 S-49 also showed higher yield/plant [5.78, 5.44, 5.72, 5.33 and 5.30g, respectively] with early maturity [80.33, 81, 83, 83 and 84.33 days, accordingly] than check varieties (BARI sarisha-6 and BARI sarisha-15). [Table 2] 


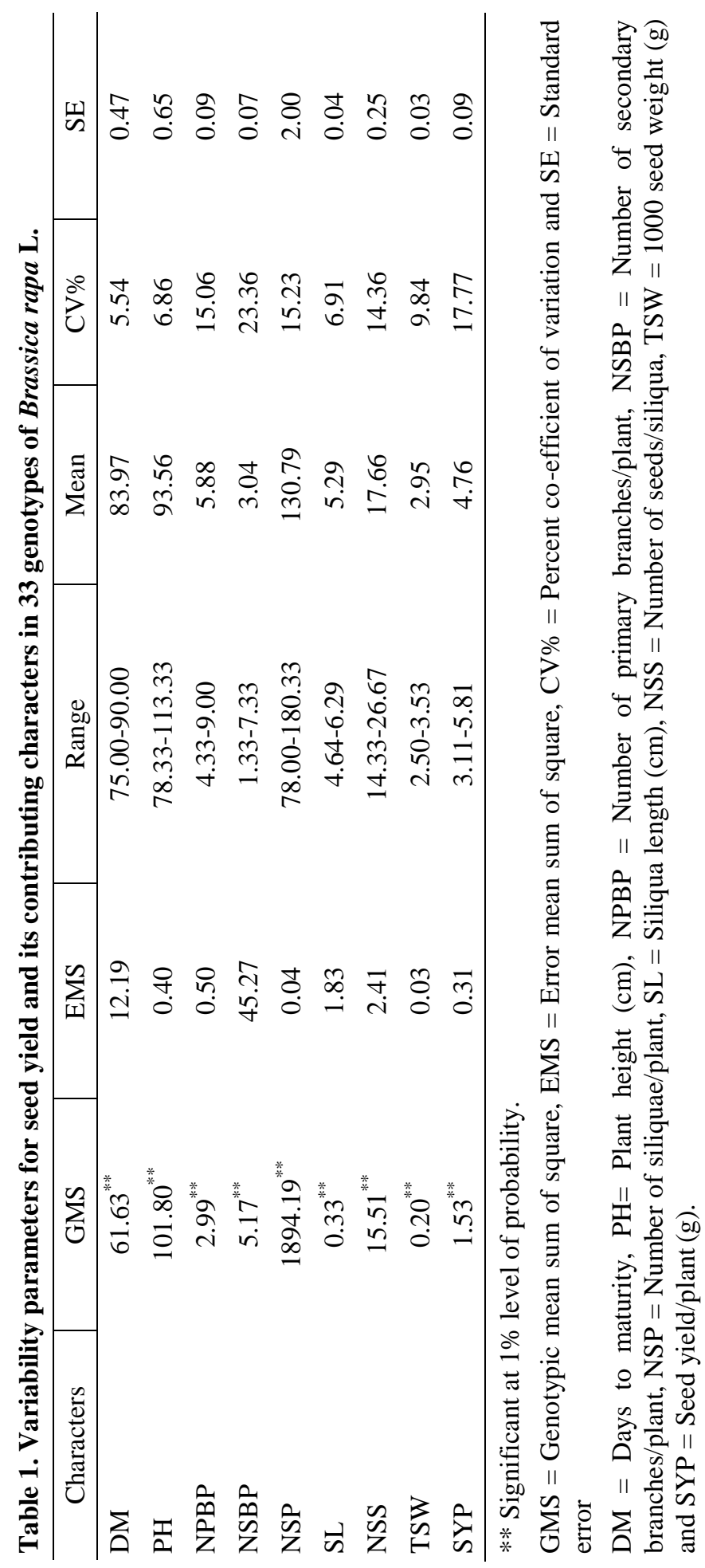




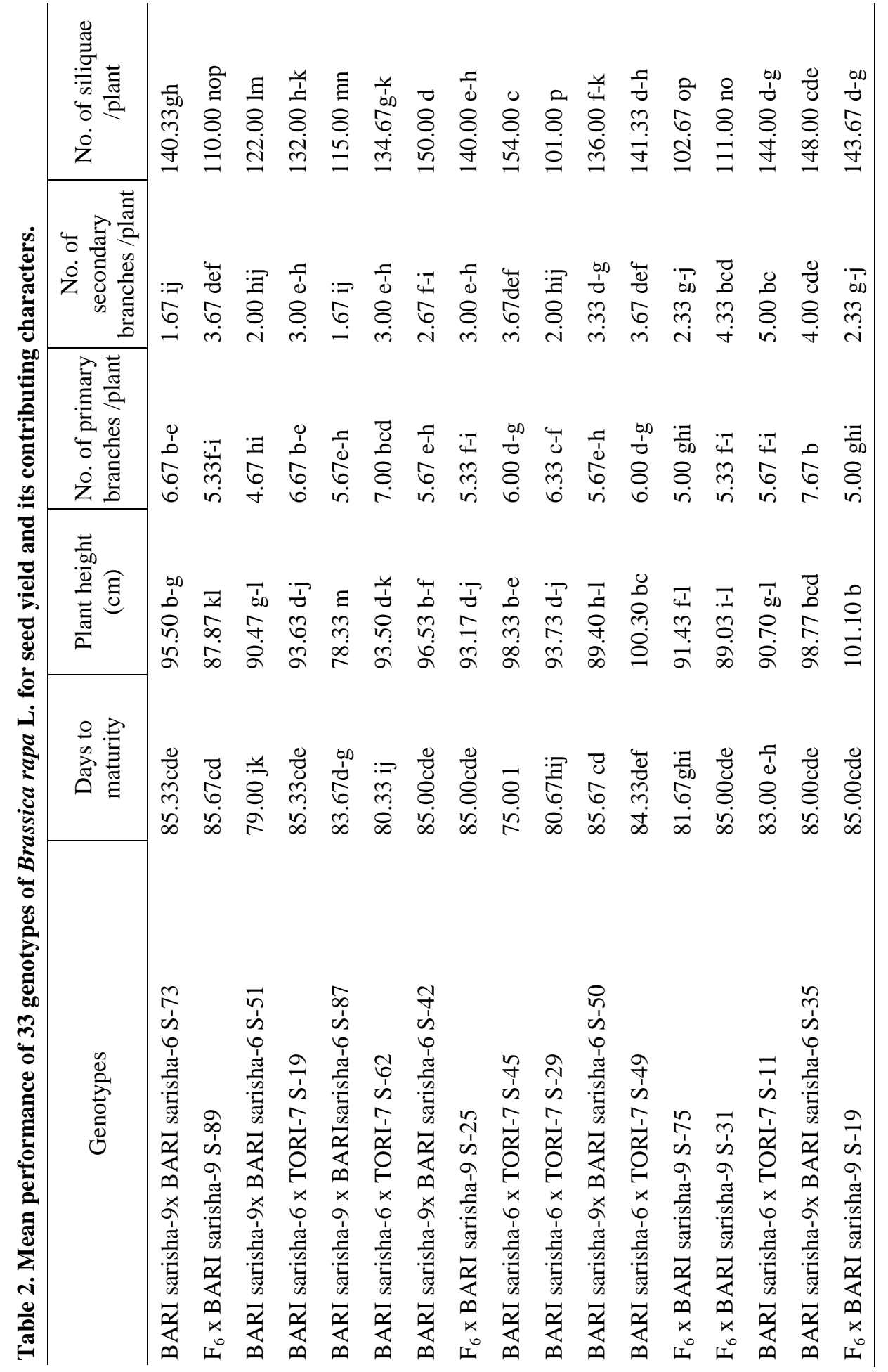




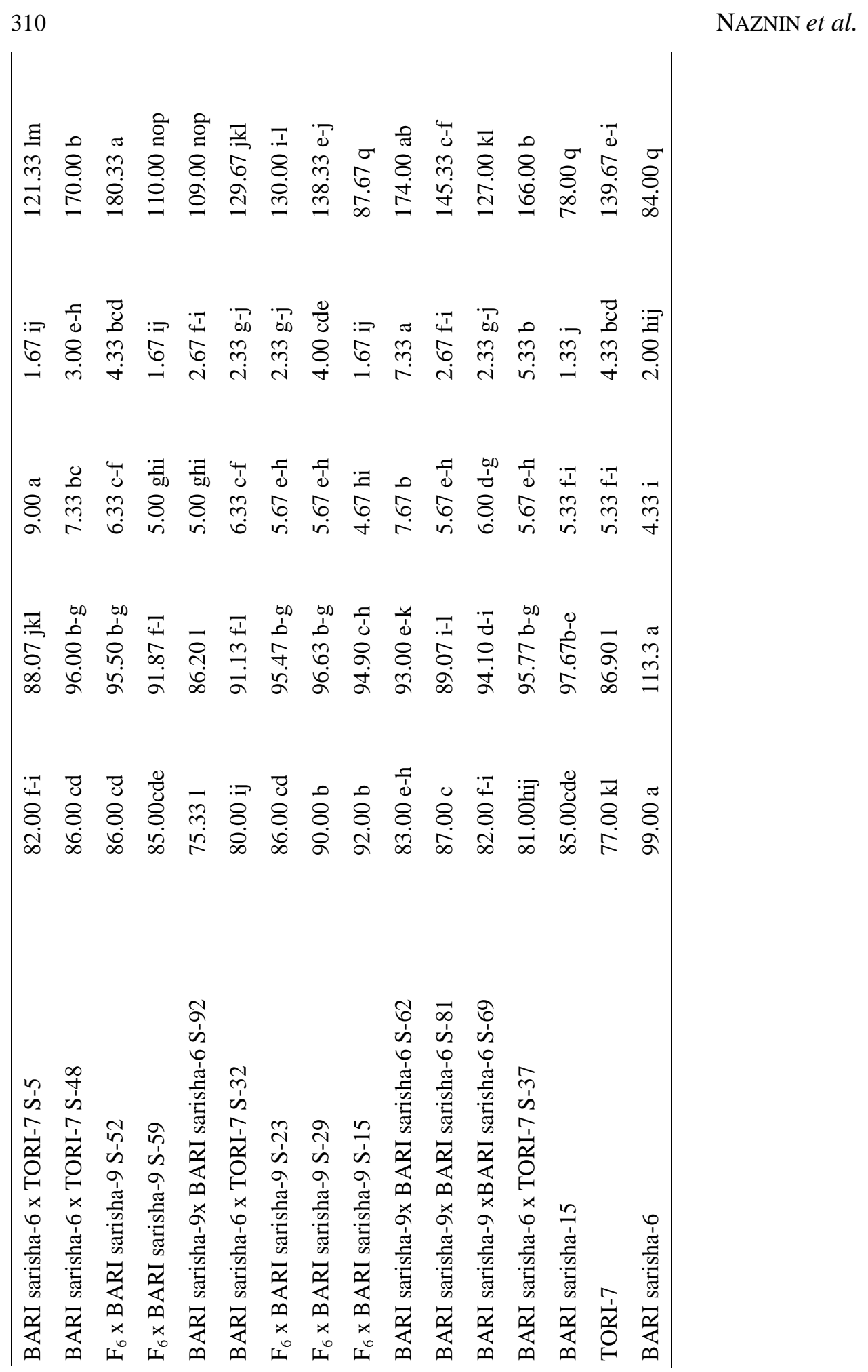


GENETIC VARIABILITY, CHARACTER ASSOCIATION AND PATH ANALYSIS

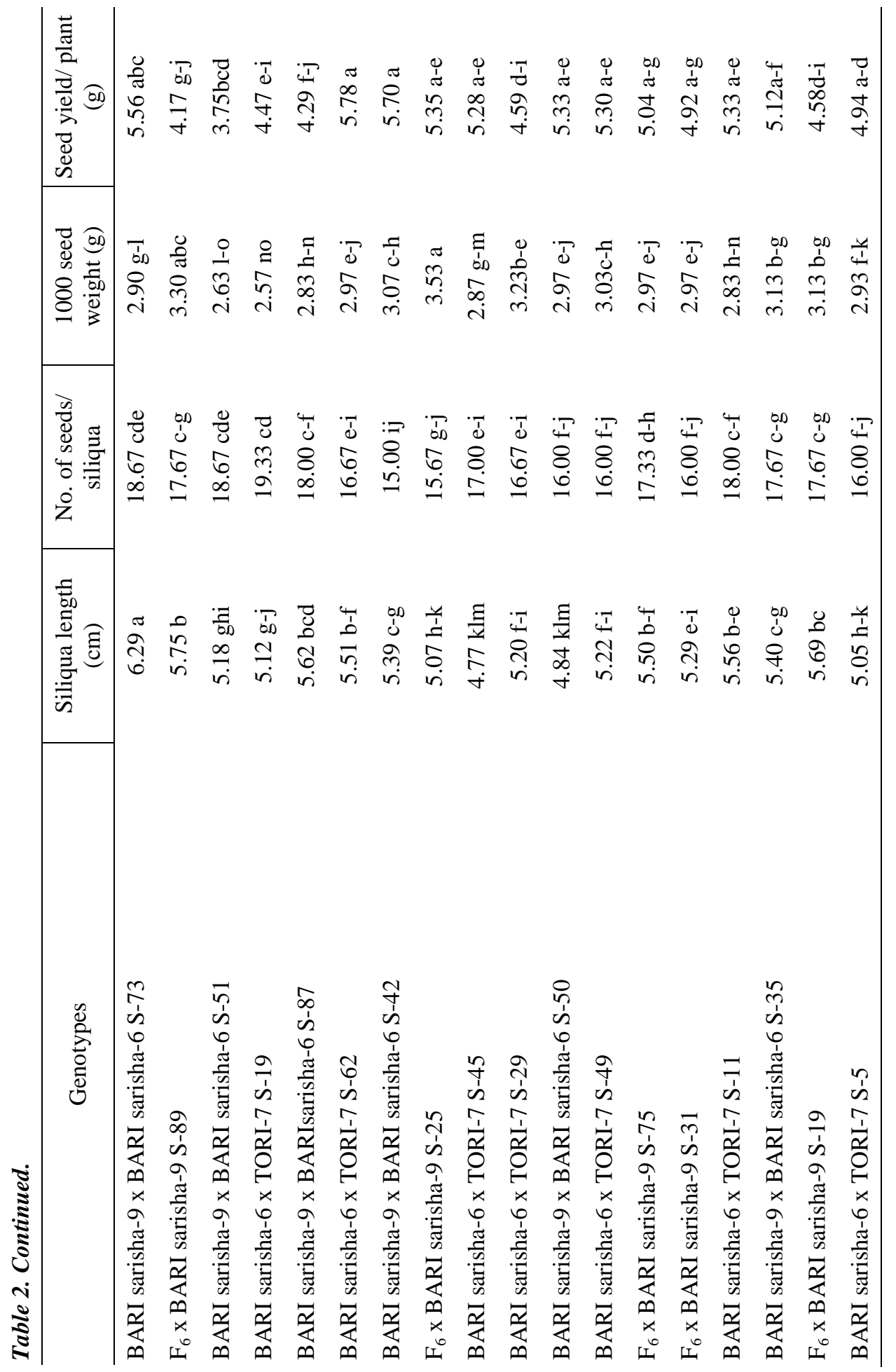




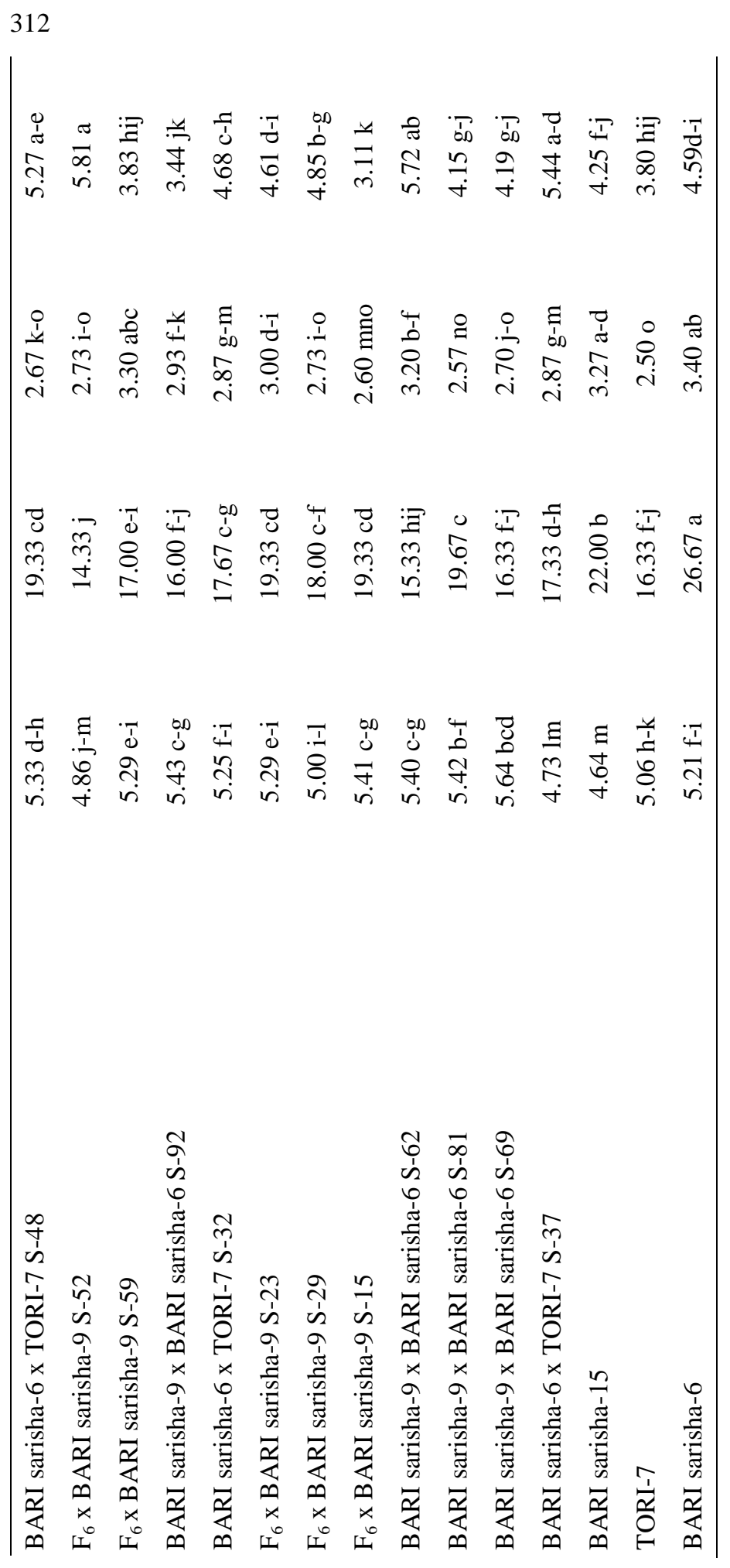

NAZNIN et al. 
Yield is polygenically controlled and highly influenced by environment; selection based on yield alone is not effective. The range of mean values also could present a rough estimate about the variation of magnitude of divergence present among different genotypes. But genotypic and phenotypic coefficients of variation are of greater use in determining the extent of variability present within the materials. In the present investigation, the phenotypic variance and phenotypic coefficient of variation were higher than the corresponding genotypic variance and genotypic coefficient of variation for all the characters under study but in many cases, the two values differed only slightly suggesting the presence of environmental influence to some extent in the expression of these characters. On the other hand plant height showed the phenotypic variance (42.06) was much higher than the corresponding genotypic variance (29.87) which indicated that there was large influence of environment on this character. Number of siliquae/plant showed highest phenotypic variance (661.58) and genotypic variance (616.31). High genotypic variance indicates the better transmissibility of the character from parent to their offspring (Ushakumari et al., 1991). Number of primary branches/plant showed low differences between the phenotypic variance (1.27) and genotypic variance (0.86) which indicated that there was less influence of environment on this character. Hosen (2008) showed least difference between phenotypic and genotypic variances for number of primary branches/plant. Low environmental influence was also observed in rest of the characters (number of siliquae/plant, number of secondary branches/plant, siliqua length, number of seeds/siliqua and thousand seed weight and seed yield/plant). Number of secondary branches/plant showed the highest phenotypic coefficient of variation (47.33) and genotypic coefficient of variation (41.17) which indicated that the genotypes were highly variable for this trait. The high phenotypic coefficient of variation and genotypic coefficient of variation observed are the evident of their high genetic variability that in turn offers good scope for selection. Yin (1989) reported the highest genotypic co-efficient of variation for number of secondary branches/plant. The moderate value of phenotypic coefficient of variation (19.67) and genotypic coefficient of variation (18.98) was observed for number of siliquae/plant which indicated the existence of adequate variation among the genotypes. Higher estimates of genotypic coefficient of variation was also observed by Rashid (2007) and maximum genotypic and phenotypic coefficients of variability were found for number of siliquae/plant by Ali et al. (2003). Moderate value of phenotypic coefficient of variation and genotypic coefficient of variation was observed for number of primary branches/plant, number of seeds/siliqua and seed yield/plant indicated the presence of considerable variability among the genotypes. Days to maturity showed low phenotypic coefficient of variation (5.60) and genotypic coefficient of variation (5.29) which indicated that the genotypes showed less variation for this trait. Sharma (1984) found low genotypic coefficient of variation and phenotypic coefficient of variation values. Less variation among the genotypes also showed in plant height, siliqua length and thousand seed weight. [Table 3] 
The coefficient of variation shows only the extent of total variability and does not separate the variability into heritable and non-heritable portion. Therefore heritable variation can be found out with the greater degree of accuracy when heritability is studied in conjunction with genetic advance. Number of siliquae/plant showed high heritability $(93.16 \%)$ with high genetic advance in percent of mean (37.74\%). Similar result was also found by Rameeh (2013) for this trait. Number of secondary branches/plant exhibited high heritability (75.69\%) with very high genetic advance in percentage of mean $(73.55 \%)$. Mahmud (2008) found high heritability values along with high genetic advance in percentage of mean for number of secondary branches/plant. Number of seeds/siliqua and number of primary branches/plant showed high heritability (71.36\% and $68.03 \%$, respectively) coupled with high genetic advance in percentage of mean (21.04\% and $26.82 \%$, accordingly). Similar result was also reported by Mahmud (2008) for number of seeds/siliqua and number of primary branches/plant successively. As a whole, high heritability with high genetic advance in percent of mean indicated that the character is mostly governed by additive gene effects, hence their improvement can be done through mass selection. These results confirm the findings of Aytac et al. (2008) and Ali et al. (2003), and selection based on phenotypic performance of these characters would be judicious for future breeding program. Days to maturity, siliqua length and plant height also exhibited high heritability $(89.14 \%, 72.48 \%$ and $71.01 \%$, respectively) with moderate genetic advance in percentage of mean $(10.29 \%$, $10.36 \%$ and $10.14 \%$, accordingly). This indicated that a trait having high heritability did not essentially produce high genetic advance. However, characters showed high values of heritability coupled with moderate genetic advance suggest that greater role of non-additive gene action in their inheritance, which supported limited scope of improvement by direct selection; heterosis breeding could be useful for improving these traits (Paikhomba et al., 2014). Moderate heritability (57.05\%) and high genetic advance as percent of mean (20.85\%) was observed for seed yield/plant which also indicated limited scope for the improvement through individual plant selection (John et al., 2013). [Table 3]

Depending upon the variability, heritability and genetic advance in percentage of mean, it could be predicted that improvement by direct selection was possible in Brassica rapa $\mathrm{L}$. for traits like number of siliquae/plant, number of secondary branches/plant and number of primary branches/plant.

\section{Correlation co-efficient}

Correlation co-efficient revealed that most of the characters showed the genotypic correlation co-efficient higher than the corresponding phenotypic correlation co-efficient suggesting a strong inherent association between the 
characters studied, the phenotypic expression of the correlation being reduced under the influence of the environment. Similar result was found by Pankaj et al. (2002). In few cases, phenotypic correlation co-efficient were higher than their corresponding genotypic correlation co-efficient suggesting that both environmental and genotypic correlation acted in the same direction and finally maximized their expression at phenotypic level.

However, number of siliquae/plant showed highly significant positive interaction with seed yield/plant $\left(r_{g}=0.7011^{* *}, r_{p}=0.5684^{* * *}\right)$. Rameeh (2011) also reported that number of siliquae/plant had significant positive correlation $\left(0.80^{* *}\right)$ with seed yield. So any change or variation for this trait will have considerable effect on seed yield/plant. Similar result was also found by Esmaeeli-Azadgoleh et al. (2009) and Marjanovic-Jeromela et al. (2007). Seed yield/plant showed positive significant interaction with number of primary branches/plant $\left(r_{\mathrm{g}}=0.5611^{* *}, \mathrm{r}_{\mathrm{p}}=\right.$ $\left.0.4016^{*}\right)$ and number of secondary branches/plant $\left(r_{\mathrm{g}}=0.5160^{* *}, \mathrm{r}_{\mathrm{p}}=0.4098^{*}\right)$ at both genotypic and phenotypic level. That indicated that branching was an important contributor to seed yield/plant, this result supported by Thurling and Das (1980). [Table 4]

On the other hand, seed yield/plant had negative significant interaction with number of seeds/siliqua $\left(r_{\mathrm{g}}=-0.4239^{*}\right)$ at genotypic level and negative nonsignificant interaction at phenotypic level $\left(\mathrm{r}_{\mathrm{p}}=-0.1824\right)$. Malik et al., (2000) reported that number of seeds/siliqua had negative correlation with seed yield/plant. Siliqua length also showed negative non-significant interaction with seed yield/plant $\left(r_{\mathrm{g}}=-0.1014, \mathrm{r}_{\mathrm{p}}=-0.0246\right)$ at both the levels. Nasim et al. (1994) found significant negative correlation between seed yield/plant and siliqua length. [Table 4]

Seed yield/plant showed non-significant positive interaction with thousand seed weight $\left(r_{g}=0.2254, r_{p}=0.078\right)$ and plant height $\left(r_{g}=0.2813, r_{p}=0.2426\right)$ at both the genotypic and phenotypic level. Days to maturity showed highly significant positive interaction with number of seeds/siliqua $\left(r_{g}=0.6450^{* * *}, r_{p}=0.5105^{* * *}\right)$ and plant height $\left(r_{g}=0.5576^{* *}, r_{p}=0.4508^{*}\right)$ at the both genotypic and phenotypic level and negative non-significant interaction with seed yield/plant $\left(\mathrm{r}_{\mathrm{g}}\right.$ $=-0.365)$ at genotypic level which indicated that if days to maturity decrease then all of the negatively associated parameter increase as well as yield increases. Number of siliquae/plant showed positive significant interaction with number of primary branches/plant $\left(r_{\mathrm{g}}=0.4920^{* *}, \mathrm{r}_{\mathrm{p}}=0.4093^{*}\right)$ and number of secondary branches/plant $\left(r_{\mathrm{g}}=0.6868^{* *}, r_{\mathrm{p}}=0.5760^{* * *}\right)$ at both the levels. [Table 4]

The results of correlation co-efficient indicated that number of siliqua/plant, number of primary branches/plant and number of secondary branches/plant were considered to be important characters for yield improvement in Brassica rapa $\mathrm{L}$. 


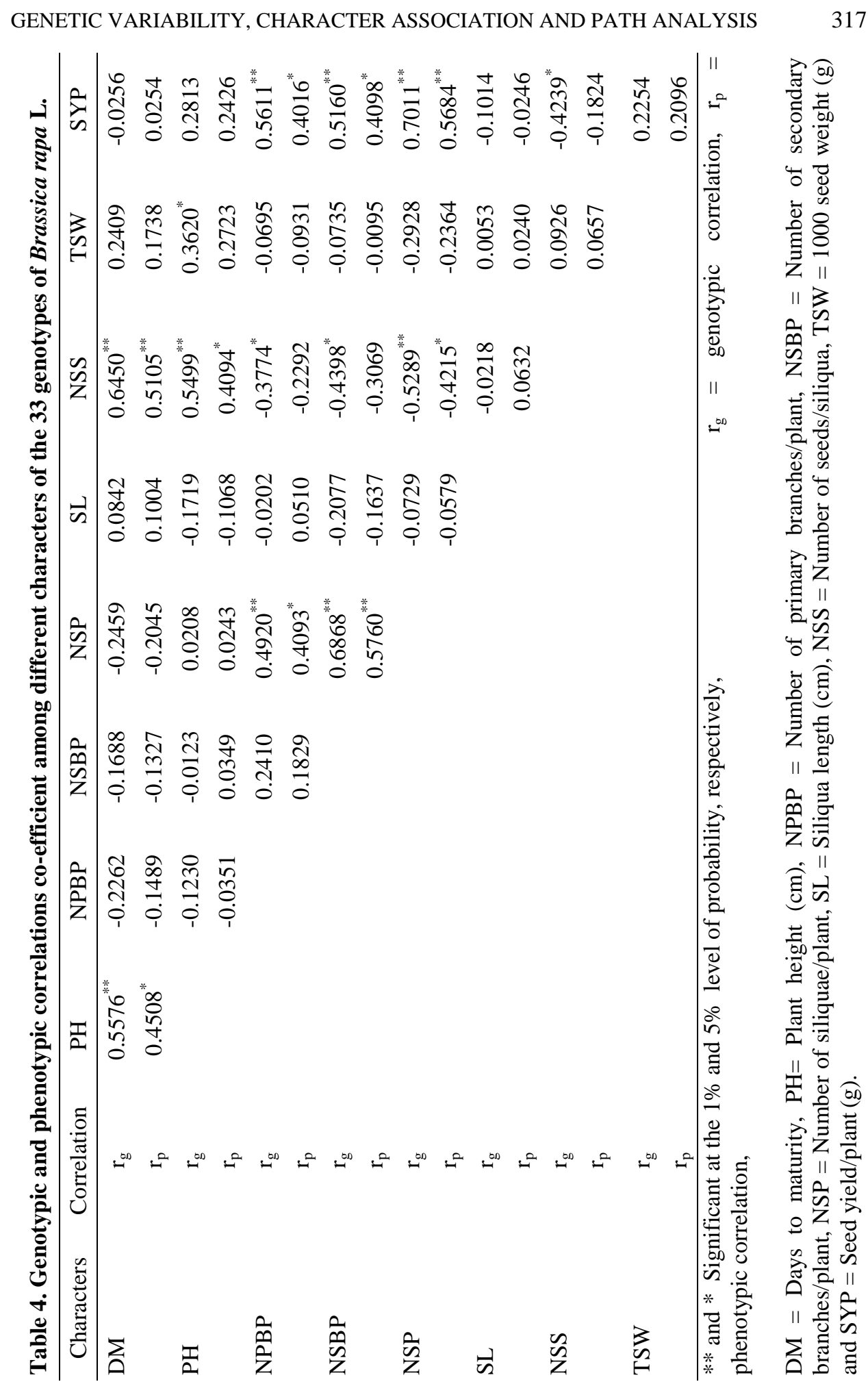




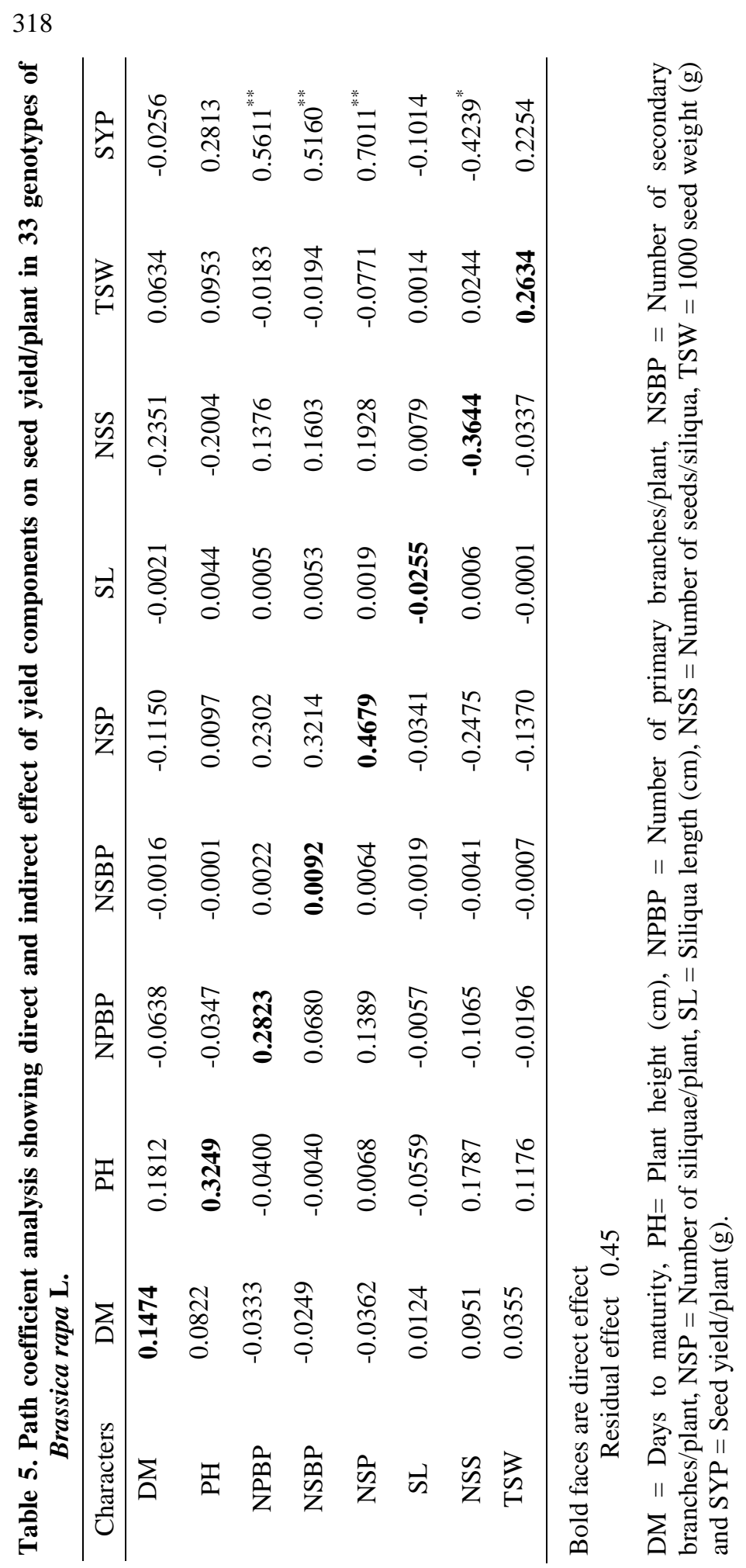

NAZNIN et al. 


\section{Path analysis}

Association of characters determined by correlation co-efficient may not provide an exact picture of the relative importance of direct and indirect influence of each yield components on yield. Correlation co-efficients were partitioned into direct and indirect effect to find out a clear picture of the inter-relationship between yield and other yield attributes by using path analysis.

Path coefficient analysis showed that the number of siliquae/plant had maximum positive direct effect on seed yield/plant (0.4679). It had positive indirect effect on yield via number of seeds/siliqua $(0.1928)$ followed by number of primary branches/plant (0.1389), plant height (0.0068), number of secondary branches/plant (0.0064) and siliqua length (0.0019) and negative indirect effect were found on thousand seed weight $(-0.0771)$ and days to maturity $(-0.0362)$. Finally it made highly significant positive correlation with seed yield/plant $\left(\mathrm{r}_{\mathrm{g}}=\right.$ $0.7011^{* * *}$ ). The genotypic correlation of number of siliquae/plant with seed yield/plant was positive and considerably higher in magnitude. It is mainly due to high positive direct effect and positive indirect effects of other characters. Therefore, selection would be effective for number of siliquae/plant. Ara (2010) found number of siliquae/plant had the highest positive direct effect on seed yield which supported the present findings. [Table 5]

Plant height had positive direct effect on seed yield/plant (0.3249) and positive indirect effect on seed yield via thousand seed weight $(0.0953)$ followed by days to maturity (0.0822), number of siliquae/plant (0.0097) and siliqua length (0.0044). It had also negative indirect effect via number of seeds/siliqua ($0.2004)$ followed by number of primary branches/plant (-0.0347) and number of secondary branches/plant (-0.0001). It was observed to have high positive direct effects on seed yield/plant but its influence was nullified by the negative indirect effects which resulted non-significant positive correlation with seed yield/plant $\left(r_{\mathrm{g}}=0.2813\right)$. [Table 5]

Number of primary branches/plant had positive direct effect on seed yield/plant (0.2823) and positive indirect effect on seed yield/plant through number of siliquae/plant (0.2302) followed by number of seeds/siliqua (0.1376), secondary branches/plant (0.0022) and siliqua length (0.0005). Negative indirect effect through days to maturity $(-0.0333)$ followed by plant height $(-0.0400)$ and thousand seed weight (-0.0183). Finally, it had highly significant positive genotypic correlation with seed yield/plant $\left(\mathrm{r}_{\mathrm{g}}=0.5611^{* * *}\right)$. Mahmud (2008) also found the highest direct effects on seed yield/plant of Brassica spp for number of primary branches/plant. [Table 5] 
Thousand seed weight had a positive direct effect (0.2634) on seed yield/plant and positive indirect effect through days to maturity (0.0355) and plant height (0.1176). Hosen (2008) found that thousand seed weight had the highest positive direct effect on seed yield/plant. Days to maturity had direct positive effect $(0.1474)$ on seed yield/plant. This trait showed indirect positive effect on seed yield/plant through plant height $(0.1812)$ and thousand seed weight $(0.0634)$. Rashid (2007) observed that seed yield had the highest direct effect on days to maturity. Number of secondary branches/plant had positive direct effect $(0.0092)$ on yield and this trait had high positive indirect effect on yield via number of siliquae/plant (0.3214) followed by number of seeds/siliqua (0.1603), number of primary branches/plant (0.0680) and siliqua length (0.0053). Finally it made highly significant positive correlation with seed yield/plant $\left(\mathrm{r}_{\mathrm{g}}=0.5160^{* * *}\right)$. Thus increase in the seed yield/plant were not only influenced by direct effects of the number of secondary branches/plant but also by the indirect selection of genotypes with high number of secondary branches/plant could be effective. Khan (2010) also found positive direct effect with seed yield for number of secondary branches/plant. [Table 5]

Number of seeds/siliqua had a negative direct effect (-0.3644) on seed yield/plant and it had also negative significant correlation with seed yield/plant (-0.4239). The negative direct effect was mainly counter balanced by indirect positive effect of different characters. Afrin (2011) had the negative direct effect on seed yield/plant for number of seeds/siliqua. Siliqua length had also direct negative effect (-0.0255) on seed yield/plant. Han (1990) observed negative direct effect of siliqua length on seed yield. The residual effect (R) of path analysis was 0.45 , which indicated that the characters under study contributed $55 \%$ of the seed yield/plant. It is suggested that there were some other factors those contributed $45 \%$ to the seed yield/plant not included in the present study. [Table 5]

The path coefficient analysis indicated that number of siliquae/plant, number of primary branches/plant and number of secondary branches/plant were the most important contributors to seed yield/plant which could be taken in consideration for future hybridization program.

Wide variability has been found among the genotypes for all the characters. The result of the study will provide the ability of breeders to develop desirable plant types having high yield with early maturity. Analyzed value from genotypic and phenotypic coefficient of variation, heritability and genetic advance in percent of mean, correlation co-efficient and even path coefficient, number of siliquae/plant, number of primary branches/plant and number of secondary branches/plant were the such traits which could be considered for future hybridization program. 


\section{References}

Afrin, K.S., F. Mahmud, M.S.R. Bhuiyan, and M.A. Rahim. 2011. Assessment of genetic variation among advanced lines of Brassica napus L. Agronomski Glasnik 4-5: 201-226.

Ali, N., F. Javidfar, J.Y. Elmira, and M.Y. Mirza. 2003. Relationship among yield components and selection criteria for yield improvement in winter rapeseed (Brassica napus L.). Pakistan J. Bot. 35(2):167-174.

Allard, R.W. 1960. Principles of Plant Breeding. John Willey and Sons. Inc. New York. P. 36.

Anonymous, 2011. Yearbook of Agricultural Statistics of Bangladesh. Bureau of Statistics, Statistics Division, Ministry of Planning, Government Peoples Republic of Bangladesh, Dhaka. Pp.101, 322, 477.

Ara, S. 2010. Variability, Correlation and Path Coefficient in segregating population of Brassica rapa obtained through intervarietal crosses. M.S. thesis, Sher-e-Bangla Agricultural University, Department of Genetics and Plant Breeding, Dhaka, Bangladesh. Pp.46-51.

Aytac, Z., G. Kinaci, and E. Kinaci. 2008. Genetic variation, heritability and path analysis of summer rapeseed cultivars. J. Appl. Biol. Sci. 2(3): 35-39.

Burton, G.W. 1952. Quantitative inheritance in grasses. pp. 277-283. Proceeding 6th International Grassland Congress, Pennsylvania. 17-23 August. Pennsylvania State College, State College, Pennsylvania, USA.

Dewey, D.R., and K.H. Lu. 1959. A correlation and path coefficient analysis of components of crested wheat grass seed production. Agron. J. 51: 515-518.

Esmaeeli-Azadgoleh, M.A., M. Zamani, and Y. Esmaeil. 2009. Agronomical important traits correlation in rapeseed (Brassica napus L.) genotypes. Res. J. Agric. Biol. Sci. 5(5): 798-802.

Han, J.X. 1990. Genetic analysis on oil content in rapeseed (Brassica napus L.). China Oilseed Crops 2: 1-6.

Hasanuzzaman, M., and M.F. Karim. 2007. Performance of rapeseed (Brassica campestris L) cv. SAU sarisha 1 under different row spacing and irrigation levels. Res. J. Biol. Sci. 3(6): 960-965.

Hosen, M. 2008. Variability, correlation and path analysis in $F_{3}$ materials of Brassica rapa. M.S. thesis, Sher-e-Bangla Agricultural University, Department of Genetics and Plant Breeding, Dhaka, Bangladesh. Pp.31-62.

John, K., R.P. Vasanthi, K. Sireesha, and T.G. Krishna. 2013. Genetic variability studies in different advanced breeding genotypes of spanish bunch groundnut (Arachis hypogeae). International Journal of Applied Biology and Pharmaceutical Technology 4(2): 185-187.

Johnson, H.W., H.F. Rabinson, and R.E. Comstock. 1955. Estimation of genetic and environmental variability in soybean. Agron. J. 47: 314-318. 
Khaleque, M.A. 1985. A guide book on production of oil crops in Bangladesh. DAE and FAO/UNDP project BGA/79/034, strengthening the Agricultural Extension Service Khamarbari, Farmgate, Dhaka. P.3.

Khan, M.M.H. 2010. Diversity analysis among 32 genotypes of Brassica rapa. M.S. thesis, Sher-e-Bangla Agricultural University, Department of Genetics and Plant Breeding, Dhaka, Bangladesh. Pp. 59-64.

Mahmud, M.A.A. 2008. Intergenotypic variability study in advanced lines of Brassica rapa. M.S. thesis, Sher-e-Bangla Agricultural University, Department of Genetics and Plant Breeding, Dhaka, Bangladesh. Pp.40-69.

Malik, M.A., A.S. Khan, Shafiullah, M.A. Khan, B.R. Khan, and A.S. Mohamand. 2000. Study of correlation among morphological parameters in different varieties/accessions of Brassica species. Pakistan J. Biol. Sci. 3(7):1180-1182.

Marjanovic-Jeromela, A., R. Marinkovi, A. Miji, Z. Zduni, S. Ivanovska, and M. Jankulovsk. 2007. Correlation and path analysis of quantitative traits in winter rapeseed (Brassica napus L.). Agriculturae Consp. Sci. 73(1):13-18.

Mary, S.S., and A. Gopalan. 2006. Dissection of genetic attributes yield traits of fodder cowpea in $\mathrm{F}_{3}$ and $\mathrm{F}_{4}$. J Appl. Sci. Res. 2:805-808.

Miller, P.A. J.G. Williams, H.F. Robinson, and R.E. Comstock. 1958. Estimates of genotypic and environmental variances and co-variances in upland cotton and their implication in selections. Agron. J. 501:126-131.

Nasim, M., L. Rahman, M.A. Quddus, and M. Shah-E-Alam. 1994. Correlation and path analysis in Brassica campestris L. J. Agric. Res. 21(10):15-23.

Pankaj, S., T. Gyanendra, A.S. Gontia, V.D. Patil, and P. Shah. 2002. Correlation studies in Indian Mustard. Agril. Sci. Digest. 22(2):79-82.

Paikhomba, N., A. Kumar, A.K. Chaurasia, and P.K. Rai. 2014. Assessment of genetic parameters for yield and yield components in hybrid rice and parents. Journal of Rice Research 2:117.

Rameeh, V. 2011. Correlation and path analysis in advanced lines of rapeseed (Brassica napus) for yield components. J. Oilseed Brassica 2(2):56-60.

Rameeh, V. 2013. Multivariate analysis of some important quantitative traits in rapeseed (Brassica napus L.) advanced lines. J. Oilseed Brassica 4(2):75-82.

Rashid, M.H. 2007. Characterization and diversity analysis of the oleiferous Brassica species. M.S. thesis, Sher-e-Bangla Agricultural University, Department of Genetics and Plant Breeding, Dhaka, Bangladesh. pp.34-63.

Robinson, H. I., R. E. Comstock, and P. H. Harvey. 1949. Estimation of heritability and degree of dominance in corn. Agron. J. 41:353-359.

Sabaghnia, N., H. Dehghani, B. Alizadeh, and M. Mohghaddam. 2010. Interrelationships between seed yield and 20 related traits of 49 canola (Brassica napus L.) genotypes in non-stressed and water-stressed environments. Spanish J. Agric. Res. 8:356-370.

Sharma, S.K. 1984. Variation and correlation studies in Indian mustard (Brassica juncea). Indian J. Agril. Sci. 54(2):146-147. 
Singh, R.K., and B.D. Chaudary. 1985. Biometrical methods in quantitative genetic analysis. Kalyani Publishers, New Delhi, India.p.56.

Shivasubramanian, S., and M. Menon. 1973. Heterosis and inbreeding depression in rice. .Madras Agric. J. 6:1139-1140.

Shukla, S., A. Bhargava, A. Chatterjee, A. Srivastava, and S.P. Singh. 2006. Genotypic variability in vegetable amaranth (Amaranthus tricolor L.) for foliage yield and its contributing traits over successive cuttings and years. Euphytica 151:103-110.

Thurling, N., and L.D.V. Das. 1980. The relationship between pre-anthesis development and seed yield of spring rape (Brassica napus L.). Australian J. Agric. Res. 31:25-36.

Ushakumari, R.M., M. Subramanian, and Subramaniam. 1991. Studies on coefficient of variation and heritable components of some quantitative characters of Brinjal. Indian J. Hort. 48(1):75-78.

Yin, J.C. 1989. Analysis on ecological, physiological and production characteristics of high quality rapeseed cultivars. Acta Agril. Shanghai. 5(4):25-32. 